\title{
Derivation of regional hazardous doses for amphibians acutely exposed to ionising radiation
}

\author{
S. Fuma, I. Kawaguchi, Y. Watanabe, Y. Kubota, T. Ban-nai and S. Yoshida \\ Research Center for Radiation Protection, National Institute of Radiological Sciences, \\ 4-9-1 Anagawa, Inage-ku, Chiba 263-8555, Japan
}

\begin{abstract}
Estimation of 50\% lethal doses from nuclear DNA contents and subsequent species sensitivity distribution analysis was performed to derive regional $5 \%$ hazardous doses $\left(\mathrm{HD}_{5}\right)$ for major orders Anura (e.g., frogs) and Caudata (e.g., salamanders) of amphibians inhabiting Japan, Australia, France, Czech Republic, Canada and some US states, where nuclear power plants or uranium mines are located. The $\mathrm{HD}_{5}$ values ranged from 3.0 to $7.7 \mathrm{~Gy}$ for the Anura inhabiting there while they ranged from 2.9 to $4.6 \mathrm{~Gy}$ for the Caudata. Comparison of these results with the worldwide $\mathrm{HD}_{5} \mathrm{~s}(5.3 \mathrm{~Gy}$ for the Anura and $3.3 \mathrm{~Gy}$ for the Caudata) suggests that benchmark values for the Asian and Oceanic Anura and the European Caudata can be set at higher doses than the global values. Regional differences should be, therefore, considered when benchmark values are derived for some taxonomic groups.
\end{abstract}

\section{INTRODUCTION}

Recently, there have been a number of national and international initiatives that are developing frameworks to provide criteria and a methodological approach for the protection of the environment from ionising radiation [1-6]. In such frameworks, the risk level is judged by comparing dose rates to non-human biota with effect benchmark values. Some trials have been, therefore, made for estimation of benchmark values for ionising radiation [7-10]. These trials have been based on the species sensitivity distribution (SSD) approach. It has been used to estimate 5\% hazardous concentrations of chemicals $\left(\mathrm{HC}_{5} \mathrm{~s}\right)$, at which only $5 \%$ species are affected and the other $95 \%$ species are protected in the environments. However, most of $5 \%$ hazardous dose rates $\left(\mathrm{HDR}_{5} \mathrm{~s}\right)$ estimated for ionising radiation are generic, e.g., for the whole ecosystems (terrestrial + freshwater + marine ecosystems) $[8,9]$, terrestrial or freshwater ecosystems [7] and vertebrates or invertebrates [10]. Currently it is difficult to estimate $\mathrm{HDR}_{5}$ specific to each taxonomic group by SSD, because there is the limited number of effects data available to each group $[8,10]$. Since there is a large difference in radiosensitivity among taxonomic groups [11], generic benchmark values will be too strict for radioresistant groups and too generous for radiosensitive groups. It is, therefore, required to derive benchmark values specific to each taxonomic group such as family or class, which corresponds to each ICRP Reference Animal and Plant [3], as Garnier-Laplace et al. [9] pointed out.

Derivation of effect benchmark values for a specific region is also required for more adequate protection of the environments from ionising radiation. It has, however, been difficult due to lack of effects data available.

It is difficult to obtain experimentally the enough number of effects data in each taxonomic group inhabiting a specific region. Appropriate extrapolation methods are, therefore, required. It is well known that radiosensitivity almost linearly increases with nuclear parameter size such as nuclear DNA content. This relationship holds for virus, bacteria and multicellular organisms such as plants and amphibians [12]. One expects that it is much easier to estimate radiosensitivity from this relationship than to investigate radiation effects experimentally, because it is not difficult to determine DNA contents by flow cytometry or other techniques and thus a lot of DNA content data have been accumulated for various 
taxonomic groups. Recently, Watanabe et al. (manuscript in preparation for submission) re-evaluated a regression line between nuclear parameter size and $100 \%$ lethal dose rate $\left(\mathrm{LDR}_{100}\right)$ for woody plants, which had been originally determined by Sparrow et al. [13]. LDR 100 values for approximately 5000 species were estimated from this regression line and nuclear parameter size data accumulated in a database, and $\mathrm{HDR}_{5}$ s for woody gymnosperms and angiosperms were derived from applying the SSD approach to the resulting $\mathrm{LDR}_{100}$ data.

Against these backgrounds, the authors decided to estimate acute $50 \%$ lethal doses $\left(\mathrm{LD}_{50} \mathrm{~s}\right)$ for various species of amphibians, which are relatively radiosensitive and one of the ICRP Reference Animals and Plants [3], from nuclear DNA content data and subsequently to estimate 5\% hazardous dose $\left(\mathrm{HD}_{5}\right)$ by the SSD approach, assuming an accidental acute irradiation scenario. In the authors' previous study, $\mathrm{LD}_{50}$ values were estimated for 284 and 217 species of the major orders Anura (frogs and toads) and Caudata (newts and salamanders) of amphibians, respectively, and $\mathrm{HD}_{5}$ was estimated for each order in a global scale. In addition, $\mathrm{HD}_{5}$ was estimated for each order inhabiting Japan, which is one of Asian countries [14]. In this paper, $\mathrm{HD}_{5} \mathrm{~s}$ were estimated for the Anura and Caudata inhabiting some countries in Oceania, Europe and North America to demonstrate importance of derivation of regional benchmark values.

\section{METHODS}

\subsection{Country selection and inhabitant species identification}

Study countries were selected from Oceania, Europe and North America by the following the conditions:

(1) There are nuclear power plants or uranium mines.

(2) There are a lot of Anura and Caudata species whose nuclear DNA contents are known.

Australia (Oceania), France, Czech Republic (Europe), Canada and USA (North America) were selected. Since USA is a huge country and has various ecological characteristics, some states were selected by the above conditions. California (western region), Texas (middle south region), Illinois (middle north region), Pennsylvania (northeast region) and South Carolina (southeast region) were selected.

Anura and Caudata species inhabiting these countries and states were identified using the Amphibian Species of the World database in the American Museum of Natural History [15].

\section{2 $\mathrm{LD}_{50}$ estimation}

The class Amphibia consists of the following three orders: the Anura, the Caudata and the Gymnophiona (Caecilians) [15]. It is known that the Anura and Caudata, which are major orders of Amphibia, fall on the following different regression lines between nuclear DNA content (in pg) and $\mathrm{LD}_{50}$ (in roentgen) [16]:

$$
\begin{aligned}
& \text { Anura }: \log \mathrm{LD}_{50}=4.493-1.387 \log (\text { nuclear DNA content }) \\
& \text { Caudata }: \log \mathrm{LD}_{50}=3.622-0.526 \log (\text { nuclear DNAcontent })
\end{aligned}
$$

Validation of these regression lines was carried out using recent data on nuclear DNA content and $\mathrm{LD}_{50}$ in the authors' previous study [14].

Nuclear DNA content data on the Anura and Caudata species inhabiting countries and US states concerned were obtained from the Animal Genome Size Database [17], which contained 498 and 426 data records of C-values, i.e., DNA contents (in pg) per haploid genome, for the Anura and Caudata, respectively. Nuclear DNA contents were calculated by multiplying these C-values with two.

From nuclear DNA content data, $\mathrm{LD}_{50}$ values for the Anura and Caudata species were calculated using equations (1) and (2), respectively. 
Table 1. Estimated $\mathrm{LD}_{50}$ and $\mathrm{HD}_{5}$ for the Anura.

\begin{tabular}{|l|c|c|c|c|c|}
\hline $\begin{array}{l}\text { Country or US } \\
\text { state }\end{array}$ & $\begin{array}{c}\text { Number of } \\
\text { inhabitant } \\
\text { species }\end{array}$ & $\begin{array}{c}\text { Number of species } \\
\text { whose nuclear } \\
\text { DNA contents are } \\
\text { known }(\% \text { of } \\
\text { all species) }\end{array}$ & $\begin{array}{c}\text { Estimated } \\
\text { LD }_{50} \text { range, } \\
\text { Gy }\end{array}$ & $\begin{array}{c}\text { HD }_{5}, \text { Gy } \\
(95 \% \\
\text { confidence } \\
\text { interval) }\end{array}$ & Reference \\
\hline Whole world & 5858 & $284(4.8)$ & $3.3-128$ & $5.3(5.3-5.4)$ & {$[14]$} \\
\hline Japan & 48 & $12(25)$ & $6.5-16.8$ & $6.9(6.3-7.6)$ & {$[14]$} \\
\hline Australia & 228 & $17(7.5)$ & $5.9-128$ & $7.7(6.5-9.0)$ & This study \\
\hline France & 25 & $16(64)$ & $5.6-35$ & $5.3(4.8-5.8)$ & This study \\
\hline Czech Republic & 12 & $12(100)$ & $4.1-16$ & $4.9(4.1-5.7)$ & This study \\
\hline Canada & 19 & $11(58)$ & $6.5-91$ & $3.3(1.8-5.8)$ & This study \\
\hline USA & & & & & \\
\hline California & 29 & $13(45)$ & $5.5-93$ & $3.0(2.0-4.4)$ & This study \\
\hline Texas & 43 & $23(53)$ & $5.1-93$ & $4.2(3.1-5.7)$ & This study \\
\hline Illinois & 20 & $15(75)$ & $8.1-76$ & $4.5(3.0-6.6)$ & This study \\
\hline Pennsylvania & 18 & $14(78)$ & $8.1-76$ & $4.4(2.9-6.6)$ & This study \\
\hline South Carolina & 30 & $25(83)$ & $8.1-76$ & $6.2(5.1-7.5)$ & This study \\
\hline
\end{tabular}

\section{3 $\mathrm{HD}_{5}$ estimation}

To derive the $\mathrm{HD}_{5}$ values by SSD, the $\mathrm{LD}_{50}$ values were transformed to logarithmic data and were fitted to the cumulative log-normal distribution curve. When a species had some different $\mathrm{LD}_{50}$ data, average of these $\mathrm{LD}_{50}$ values was adopted as a representative value of the species. Confidence interval was obtained from the standard error which was derived by delta method [18]. Curve-fitting and other calculations were preformed using Mathematica 7.0 (Wolfram Research, Inc., Champaign, IL, USA).

\section{RESULTS AND DISCUSSION}

From the Animal Genome Size Database [17], nuclear DNA content data were obtained in 8-28 species of the Anura or Caudata inhabiting each country or US state except for Australia which no Caudata species inhabit. This means that these data were obtained in 7.5-100\% of all the species inhabiting there. From these data, $\mathrm{LD}_{50}$ values were estimated using equations (1) and (2). The resulting $\mathrm{LD}_{50}$ ranges for the Anura and Caudata are shown in tables 1 and 2, respectively. The $\mathrm{LD}_{50}$ data were analysed by SSD to estimate $\mathrm{HD}_{5}$ values, which are shown in tables 1 and 2 together with $\mathrm{HD}_{5}$ values for the whole world and Japan estimated in the authors' previous study [14]. SSD for the Caudata in South Carolina, USA, is shown in Fig. 1 as an example.

In the authors' previous study [14], the $\mathrm{HD}_{5}$ value was $5.3 \mathrm{~Gy}$ for the worldwide Anura while it was 3.3 Gy for the worldwide Caudata, suggesting that the Caudata is more radiosensitive than the Anura in a global scale. The $\mathrm{HD}_{5}$ values ranged from 3.0 to 7.7 Gy for the Anura inhabiting countries and US states concerned while they ranged from 2.9 to 4.6 Gy for the Caudata. The Caudata showed a tendency to be more radiosensitive than the Anura in all the countries and US states except for Canada and California. Considering confidence intervals, however, the Caudata was significantly more radiosensitive than the Anura only in Japan, France and South Carolina, and no significant difference in radiosensitivities between the Anura and Caudata was observed in the other countries and US states.

The $\mathrm{HD}_{5}$ values for the Japanese and Australian Anura were significantly higher than that for the worldwide Anura, suggesting that benchmark values for the Asian and Oceanic Anura can be set at higher doses than the worldwide value. The $\mathrm{HD}_{5}$ value for the Anura inhabiting California was significantly lower than the worldwide value. Considering confidence intervals, the $\mathrm{HD}_{5}$ values for the Anura inhabiting the other countries or US states concerned were equivalent to the worldwide value. 
Table 2. Estimated $\mathrm{LD}_{50}$ and $\mathrm{HD}_{5}$ for the Caudata.

\begin{tabular}{|l|c|c|c|c|c|}
\hline $\begin{array}{l}\text { Country or US } \\
\text { state }\end{array}$ & $\begin{array}{c}\text { Number of } \\
\text { inhabitant } \\
\text { species }\end{array}$ & $\begin{array}{c}\text { Number of species } \\
\text { whose nuclear } \\
\text { DNA contents are } \\
\text { known }(\% \text { of } \\
\text { all species) }\end{array}$ & $\begin{array}{c}\text { Estimated } \\
\text { LD }_{50} \text { range, } \\
\text { Gy }\end{array}$ & $\begin{array}{c}\text { HD }_{5}, \text { Gy } \\
(95 \% \\
\text { confidence } \\
\text { interval) }\end{array}$ & Reference \\
\hline Whole world & 597 & $217(36)$ & $2.3-7.3$ & $3.3(3.3-3.4)$ & {$[14]$} \\
\hline Japan & 24 & $10(42)$ & $3.6-6.7$ & $3.4(3.1-3.7)$ & {$[14]$} \\
\hline Australia & 0 & $0(-)$ & - & - & This study \\
\hline France & 14 & $10(71)$ & $4.6-5.6$ & $4.6(4.4-4.7)$ & This study \\
\hline Czech Republic & 8 & $8(100)$ & $4.6-5.6$ & $4.6(4.5-4.7)$ & This study \\
\hline Canada & 22 & $19(86)$ & $2.8-6.9$ & $3.4(3.2-3.7)$ & This study \\
\hline USA & & & & & \\
\hline California & 42 & $25(60)$ & $3.5-5.2$ & $3.7(3.7-3.8)$ & This study \\
\hline Texas & 28 & $12(43)$ & $3.5-5.4$ & $3.6(3.3-3.9)$ & This study \\
\hline Illinois & 19 & $17(89)$ & $2.8-5.9$ & $3.3(3.0-3.6)$ & This study \\
\hline Pennsylvania & 22 & $21(95)$ & $2.8-6.9$ & $3.5(3.3-3.7)$ & This study \\
\hline South Carolina & 40 & $28(70)$ & $2.4-7.3$ & $2.9(2.8-3.1)$ & This study \\
\hline
\end{tabular}

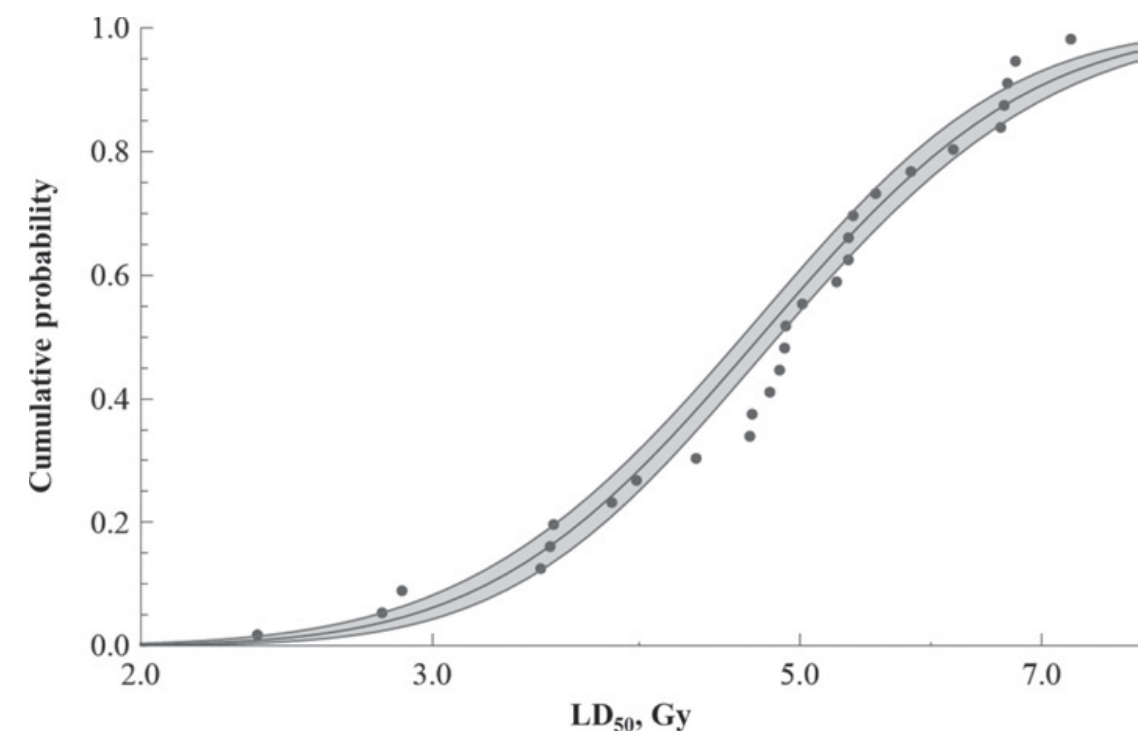

Figure 1. SSD of $\mathrm{LD}_{50}$ for the Caudata in South Carolina, USA. A shaded area represents a $95 \%$ confidence interval.

The $\mathrm{HD}_{5}$ values for the Caudata inhabiting France and Czech Republic were significantly higher than that for the worldwide Caudata, suggesting that a benchmark value for the European Caudata can be set at a higher dose than the worldwide value. The $\mathrm{HD}_{5}$ values for the Caudata inhabiting California and South Carolina, USA, were significantly higher and lower than the worldwide value, respectively. Considering confidence intervals, the $\mathrm{HD}_{5}$ values for the Caudata inhabiting the other countries or US states concerned were equivalent to the worldwide value.

These results suggest that benchmark values for the Anura and Caudata inhabiting some regions can be set at higher or lower doses than the global value. To confirm this hypothesis, further studies are required. Such studies would be, however, difficult, because the number of Anura and Caudata species whose nuclear DNA contents are known is very limited in some regions such as Southeast Asia. For example, nuclear DNA contents are known only for 7 species of the Anura in Indonesia [17], which has 
a plan to operate nuclear power plants, though 396 species of the Anura inhabit this country [15]. More data on nuclear DNA contents should be obtained in such countries.

\section{References}

[1] IAEA, Ethical Considerations in Protecting the Environment from the Effects of Ionizing Radiation. IAEA-TECDOC Series No. 1270 (IAEA, Vienna, 2002).

[2] ICRP, ICRP Publication 91. Ann. ICRP 33 (2003) 201-266.

[3] ICRP, ICRP Publication 108. Ann. ICRP 38 (2008) 1-242.

[4] OECD/NEA, Scientific Issues and Emerging Challenges for Radiological Protection - Report of the Expert Group on the Implications of Radiological Protection Science. NEA No. 6167 (OECD Publications, Paris, 2007).

[5] Howard, B.J., Beresford, N.A., Andersson, P., Brown, J.E., Copplestone, D., Beaugelin-Seiller, K., Garnier-Laplace, J., Howe, P.D., Oughton, D. and Whitehouse, P., J. Radiol. Prot. 30 (2010) 195-214.

[6] US DOE, A Graded Approach for Evaluating Radiation Doses to Aquatic and Terrestrial Biota. DOE-STD-1153-2002 (US Department of Energy, Washington, D.C., 2002).

[7] Garnier-Laplace, J., Della-Vedova, C., Gilbin, R., Copplestone, D., Hingston, J. and Ciffroy, P., Environ. Sci. Technol. 40 (2006) 6498-6505.

[8] Garnier-Laplace, J., Copplestone, D., Gilbin, R., Alonzo, F., Ciffroy, P., Gilek, M., Agüero, A., Björk, M., Oughton, D.H., Jaworska, A., Larsson, C.M. and Hingston, J.L., J Environ Radioact. 99 (2008) 1474-1483.

[9] Garnier-Laplace, J., Della-Vedova, C., Andersson, P., Copplestone, D., Cailes, C., Beresford, N.A., Howard, B.J., Howe, P. and Whitehouse, P., J. Radiol. Prot. 30 (2010) 215-233.

[10] Andersson, P., Garnier-Laplace, J., Beresford, N.A., Copplestone, D., Howard, B.J., Howe, P., Oughton, D. and Whitehouse, P., J. Environ. Radioact. 100 (2009) 1100-1108.

[11] UNSCEAR, Sources and Effects of Ionizing Radiation: UNSCEAR 1996 Report to the General Assembly, with Scientific Annex (UNSCEAR, New York, 1996).

[12] Sparrow, A.H., Underbrink, A.G. and Sparrow, R.C., Radiat. Res. 32 (1967) 915-945.

[13] Sparrow, A.H., Schwemmer, S.S., Klug, E.E. and Puglielli, L., Radiat. Res. 44 (1970) 154-177.

[14] Fuma, S., Watanabe, Y., Kawaguchi, I., Takata, T., Kubota, Y., Ban-nai, T. and Yoshida, S., manuscript in submission.

[15] Frost, D.R., Amphibian Species of the World: an Online Reference. Version 5.4 (8 April, 2010). Electronic Database accessible at http://research.amnh.org/vz/herpetology/amphibia/, American Museum of Natural History, New York, USA.

[16] Conger, A.D. and Clinton, J.H., Radiat. Res. 54 (1973) 69-101.

[17] Gregory, T.R., Animal Genome Size Database, Release 2.0 (2006) accessible at http://www.genomesize.com.

[18] Bishop, Y.M.M., Fienberg S.E. and Holland, P.W., Discrete Multivariate Analysis: Theory and Practice (The MIT Press, Cambridge, Massachusetts, 1975). 